\title{
INTERNATIONAL COMPARISON AND TREND OF EMISSIONS IN THE TRANSPORT SECTOR IN THE EUROPEAN UNION AND SLOVAKIA
}

\begin{abstract}
Transport and its major part of transport means is currently based on the internal combustion engine principle. For these engines, the primary energy source is oil, natural gas, coal, biomass and others. These primary energy sources and their processing in refineries and factories are used to produce products that are used to drive engines - fuels. From what energy sources these fuels will be produced and what technology will be used to process and produce them is also an important. This whole process must take the reduction of total emissions into account. Future fuels can be considered synthetically produced diesel or hydrogen, which can later significantly affect the decrease in emissions from their processing, production and subsequent combustion of these more environmentally friendly types of fuels. This article processes analyses and development of basic pollutants, total emissions and energy consumption in the Slovak Republic and the EU. In the second part there is an evaluation of the emissions trend development in transport in the EU and Slovakia.
\end{abstract}

Keywords: emission, pollutants, transport, environment, comparison

\section{Tomáš Čechovič ${ }^{1}$}

1 Department of Railway Transport, Faculty of Operational and Economics of Transport and Communications, University of Žilina, 01026 Žilina, Slovakia; tomas.cechovic@fpedas.uniza.sk

Martin Kendra ${ }^{2}$

2 Department of Railway Transport, Faculty of Operational and Economics of Transport and Communications, University of Žilina, 01026 Žilina, Slovakia; martin.kendra@fpedas.uniza.sk

\section{Introduction}

Today, efficient energy performance and improved environmental practices are becoming an important quality criterion in transport services. Suppliers of transport services are required to declare the impact of their activities on the environment, by quantifying the specific amount of pollutants produced and emissions from vehicle transport operations. Nowadays, one of the main pollutants nowadays is the worldwide known greenhouse gas carbon dioxide - $\mathrm{CO}_{2}$. Its production is gradually decreasing from year to year, but some countries still have difficulty in reaching the emission limits set by the European Union.

\section{Comparison of the development of the main pollutants in Slovakia and the EU}

In the long-term range between 1990 and 2016, there was a significant decrease in total emissions from the economy. Since 1990, a decreasing trend has been observed for all pollutants monitored.
In the mid-term review since 2000 , the decreasing trend continued for most of the monitored substances and the development can be considered positive. There was a slight increase in NMVOC, $\mathrm{SO}_{2}, \mathrm{PM}_{2.5}$, POPs (emissions of persistent organic pollutants from industrial processes) and also in the case of $\mathrm{Cd}$ (cadmium) emissions in the year-on-year change occurred in 2016 - 2017. Overall, the Slovak Republic has been successful in meeting the objectives of its international commitments. A summary assessment of the development of emissions of basic pollutants for the period $2000-2017$ is shown in the following figure. 


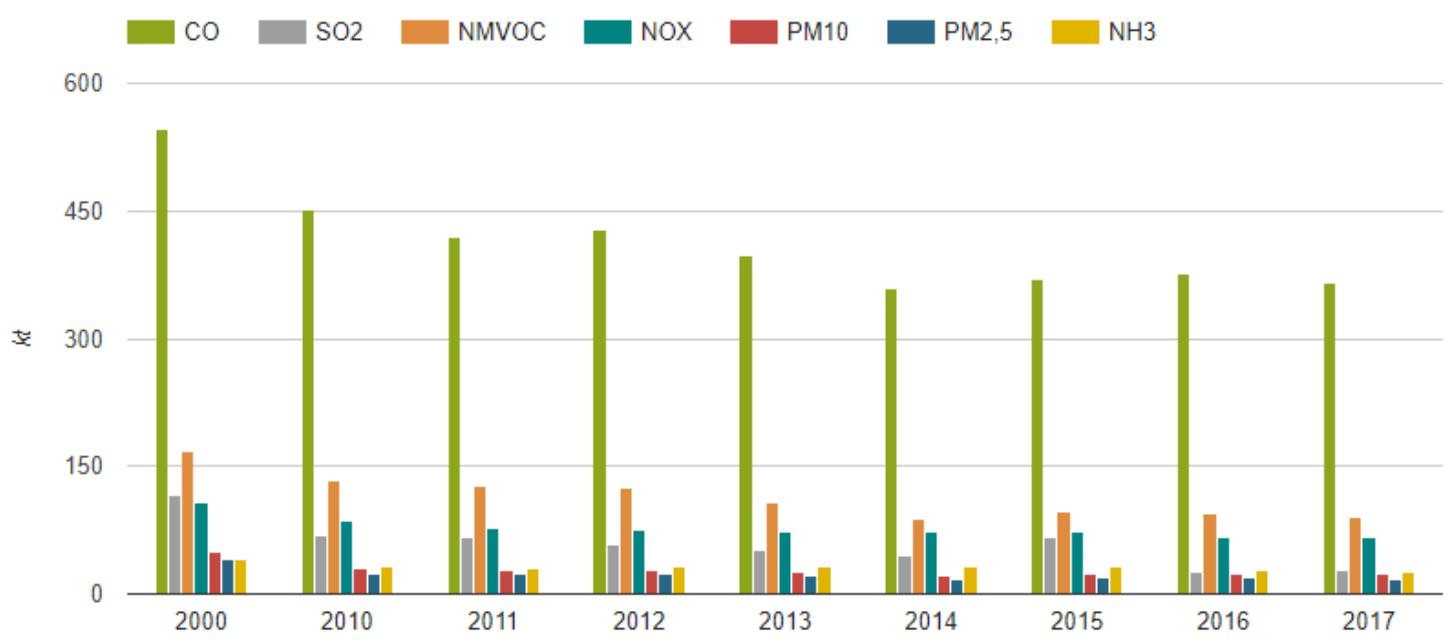

Fig. 1. Trend of emissions of basic pollutants in Slovakia

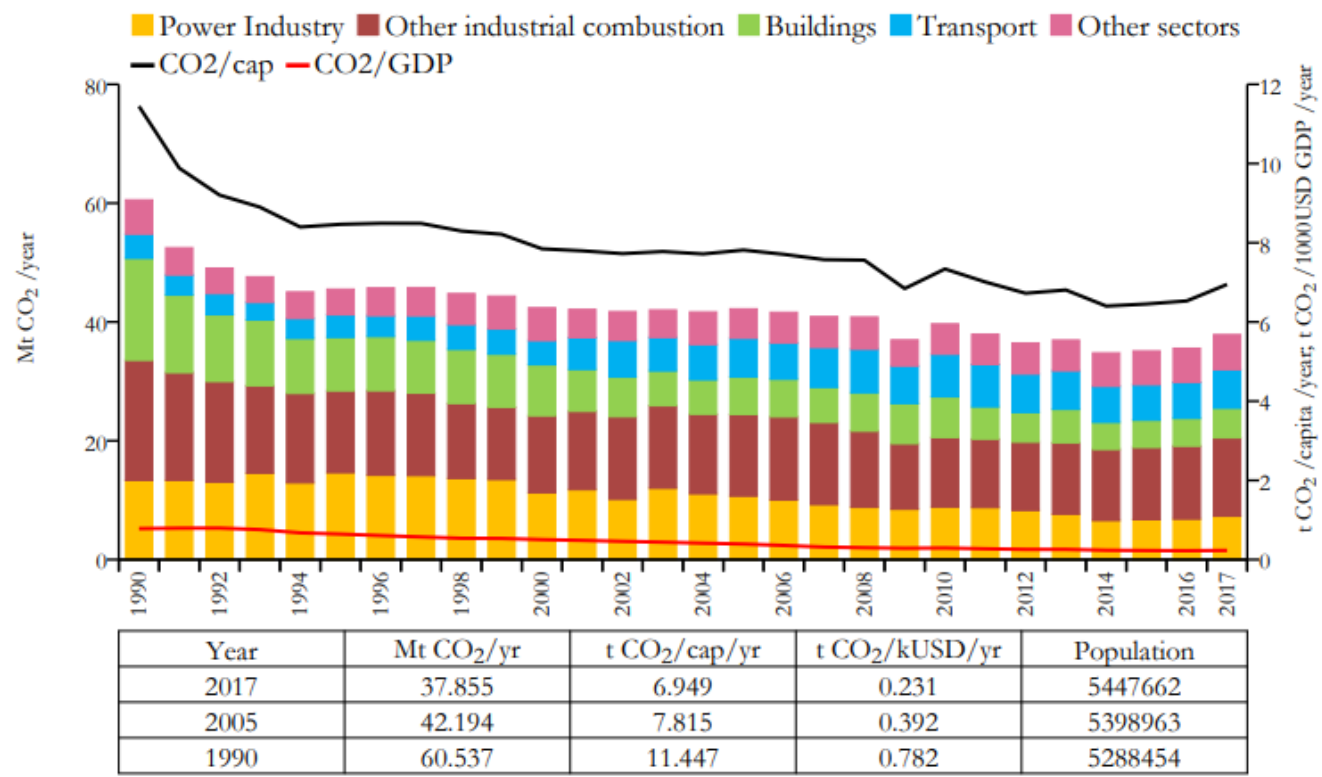

Fig. 2. Fossil $\mathrm{CO}_{2}$ emissions by sector during 1990-2017 in Slovakia
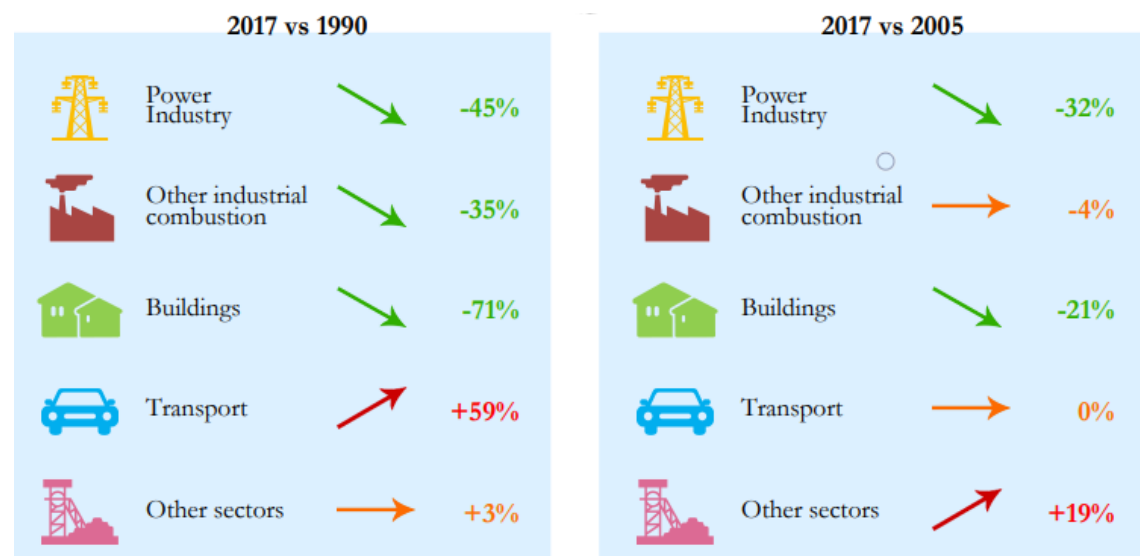

Fig. 3. Change fossil $\mathrm{CO}_{2}$ emissions by sector during 1990-2017 in Slovakia

In the long-term interval (1990 - 2016), there was a significant decrease in BP (Basic Pollutants). A comparison of the years between 2000 - 2016 showed a decrease in $\mathrm{SO}_{2}$ emissions by up to $78.5 \%$, $\mathrm{NO}_{\mathrm{X}}$ by $40.9 \%$ and $\mathrm{CO} 36 \%$. The trend in particulate emissions in the period 2000 - 2016 was decreasing, by $23 \%$ for $\mathrm{PM}_{10}$ and by $14.8 \%$ for $\mathrm{PM}_{2.5}$.

One of the reasons for this positive development was legislative and technological progress and a change in the fuel base. The development itself was also affected by a 
change in the structure and volume of industrial production.

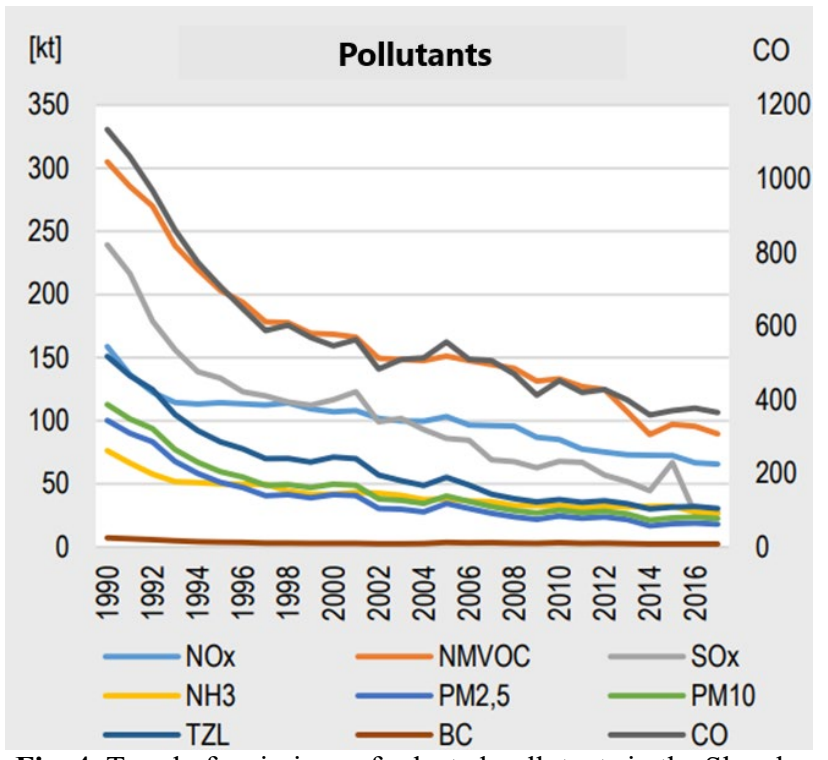

Fig. 4. Trend of emissions of selected pollutants in the Slovak Republic in 1990-2017

A comparison of the base year 2005 emissions and the currently available year 2017 emissions of selected pollutants $\mathrm{NO}_{\mathrm{X}}, \mathrm{NMVOC}, \mathrm{SO}_{\mathrm{X}}, \mathrm{NH}_{3}, \mathrm{PM}_{2.5}, \mathrm{PM} 10$, TZL(solid pollutants), CO broken down by economic sectors is shown in Figure 5. The graphs show the percentage share of emission of individual sectors nationwide balance sheet.
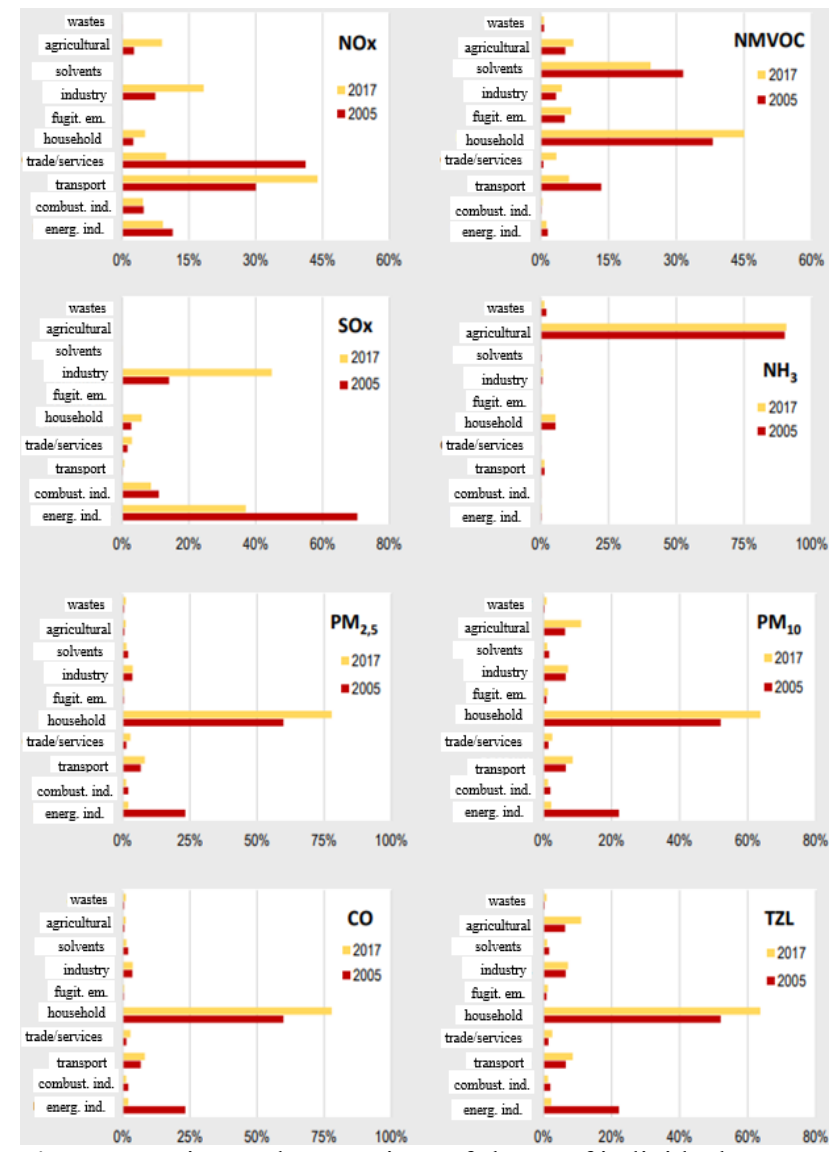

Fig. 5. Overview and comparison of shares of individual sectors in national totals

The following three figures show an international comparison of emissions $\left(\mathrm{PM}_{10}, \mathrm{SO}_{2}, \mathrm{NOx}, \mathrm{NMVOC}\right.$, $\mathrm{NH}_{3}$ ) of individual EU countries for 2016.

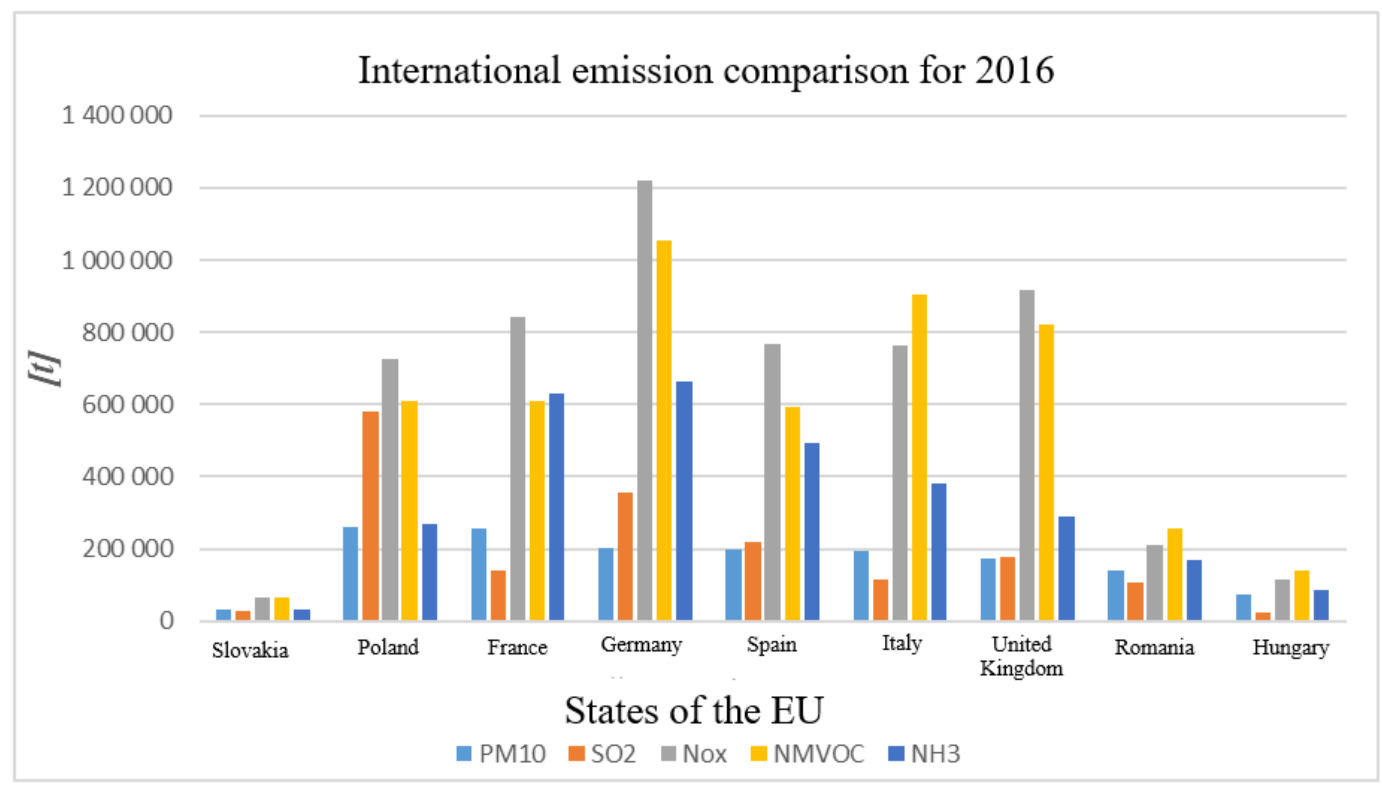

Fig. 6. International comparison of emissions of EU countries for 2016 


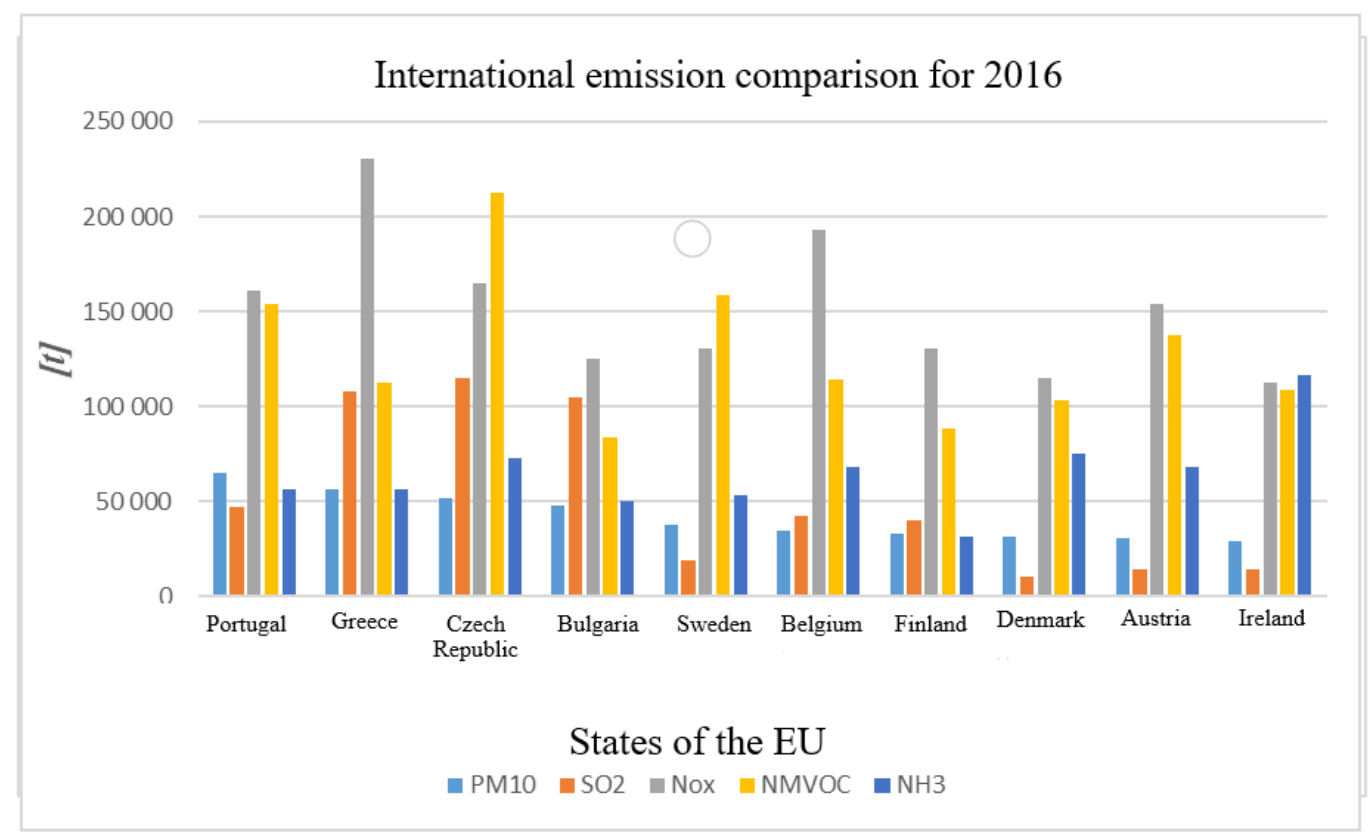

Fig. 7. International comparison of emissions of EU countries for 2016

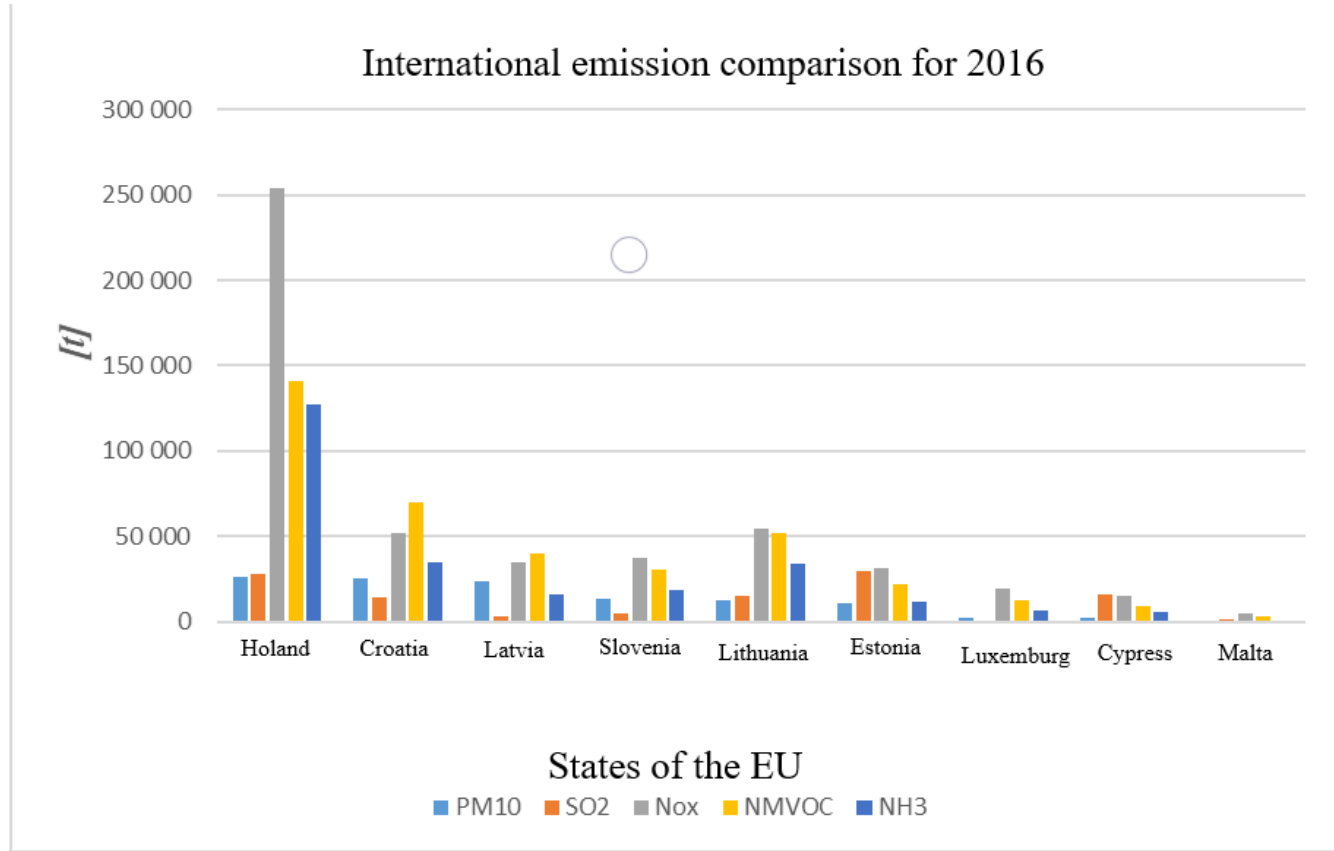

Fig. 8. International comparison of emissions of EU countries for 2016

\section{Development of final energy consumption by 2017}

Road transport accounts for the largest share of total liquid fuel consumption in the transport sector, while final electricity consumption is attributable to rail transport. The share of renewable energy (RES) in the transport sector in 2016 was $7.5 \%$. The final energy consumption for the period 2001 - 2016 in the transport sector is shown graphically in the following figure.

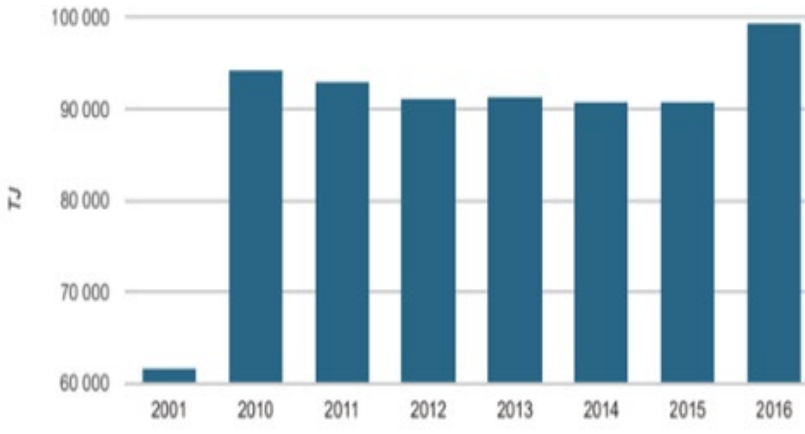

Fig. 9. Final energy consumption in transport in Slovakia 
Final energy consumption in the transport sector increased by $61 \%$ between 2001 and 2016, despite a volatile trend. The largest share of fuel consumption in the transport sector is the final consumption of liquid fuels (97\%), while the share of final consumption of solid fuels, gaseous fuels and electricity is smaller.

The growth of final energy consumption in the transport sector continued also in the following period of 2001 2017. Road transport had the largest share in fuel consumption. In rail transport, electricity consumption predominated.

\subsection{Development of transport performance in the transport sector}

In 2017, the number of transported passengers in rail and air transport increased, while road public transport and water transport recorded a more significant year-on-year decrease in the number of transported people. Transport performance compared to last year recorded a slight increase in all types of passenger transport. The share of individual transport modes in passenger transport performance is represented by individual motoring - $72 \%$, road public transport - $13 \%$, rail transport - $10 \%$, public transport $-3 \%$ and air transport - $2 \%$.

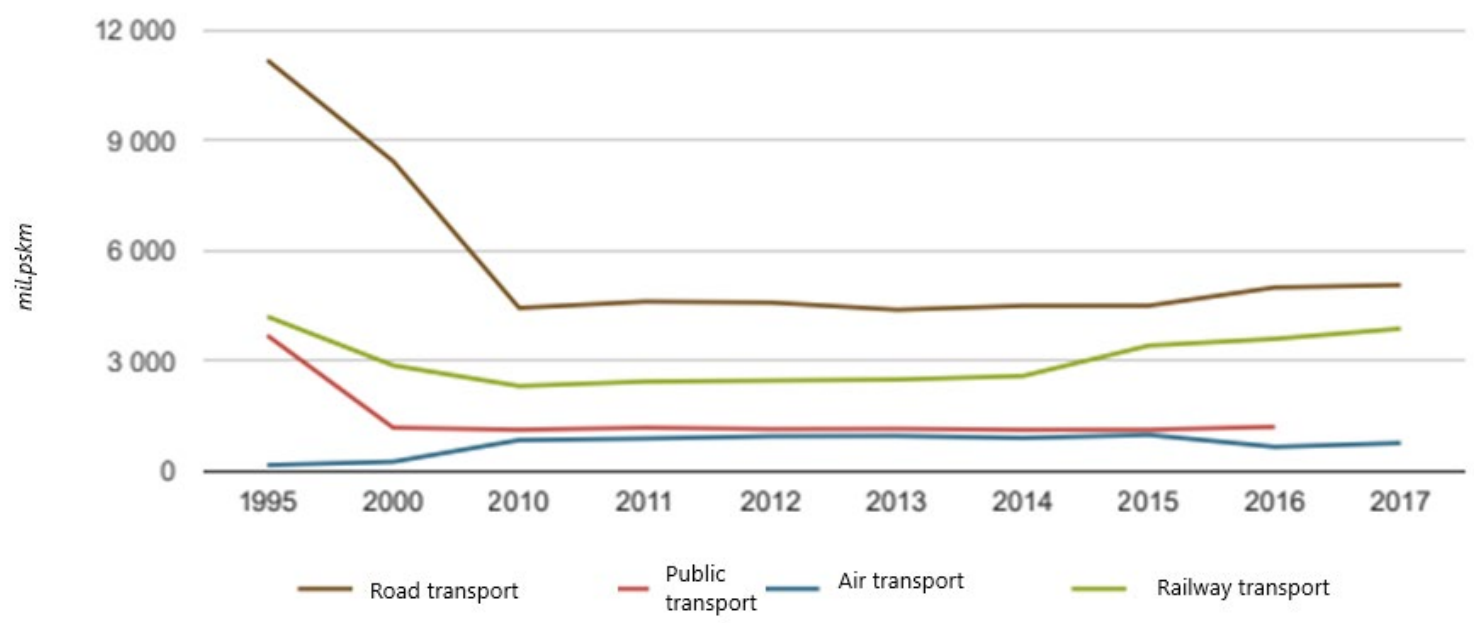

Fig. 10. Transport performance in passenger transport by type of transport in Slovakia

Freight transport performance decreased in 2017 in all transport modes except air transport. Road transport (about 79\%) accounts for the largest share of freight transport performance, followed by rail $(19 \%)$ and inland waterway transport accounts for only $2 \%$.

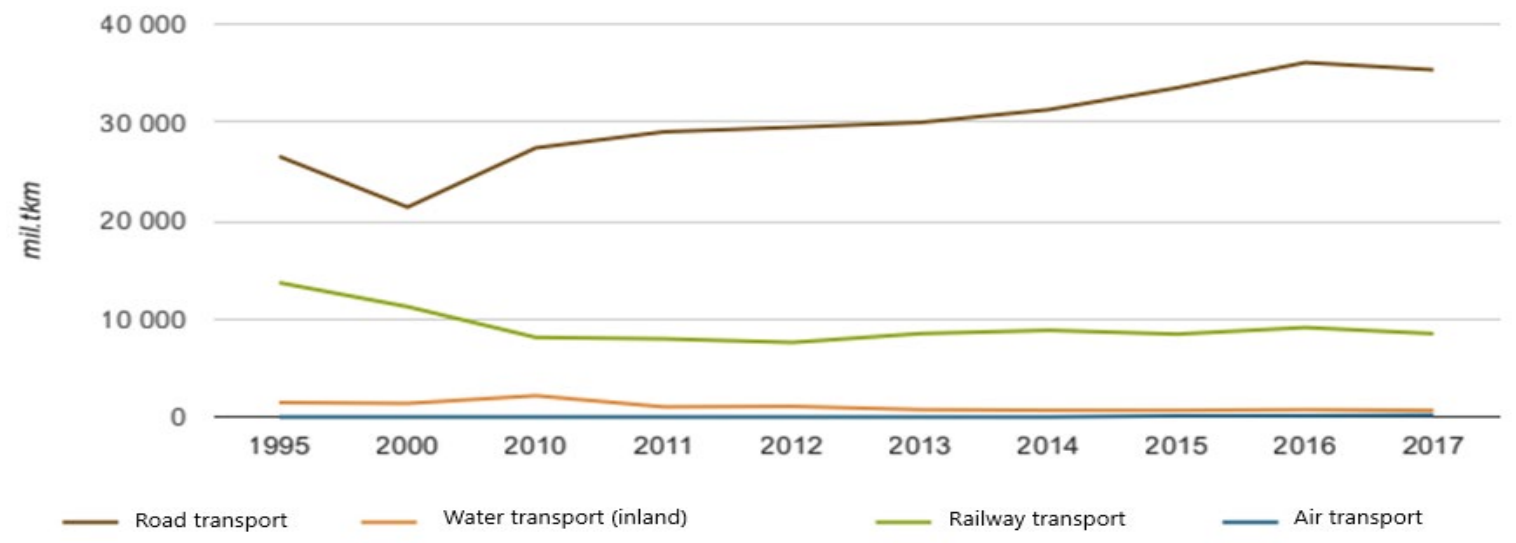

Fig. 11. Development of transport performance in freight transport by type in Slovakia

Public transport is provided by transport companies in Bratislava, Košice, Prešov, Banská Bystrica, Považská Bystrica, Púchov and Žilina. In other Slovak cities, public transport is provided by road passenger transport companies, i.e. private businesses. Such transport is not kept as public transport. In 2017, there was a year-on-year increase in the number of people transported by bus and trolleybus urban public transport. Transport of people by tram decreased year-on-year. During the period under review, bus transport keeps the leading position in 
passenger transport, followed by tram and trolleybus transport.

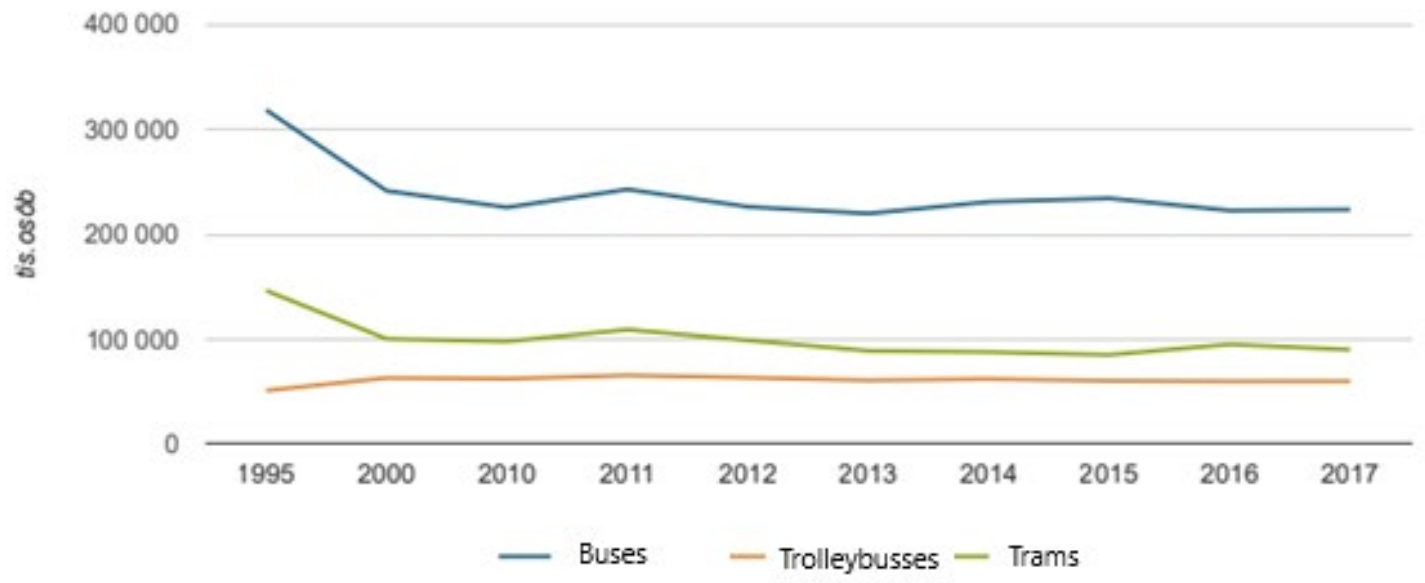

Fig. 12. Development in the number of transported persons by public transport in Slovakia.

The transport sector is considered as a significant source of emissions of nitrogen oxides $\left(\mathrm{NO}_{\mathrm{X}}\right)$ and carbon monoxide $(\mathrm{CO})$ not only in Slovakia but also globally.

\section{Evaluation of trends in transport emissions in the EU and Slovakia}

The share of transport in total EU greenhouse gas emissions is increasing. About a third of transport emissions are generated by trucks and bus. In Slovakia it is even more - up to $45 \%$. According to the European Environment Agency, in the current trends, transport is not able to meet the climate commitments resulting from the Paris Agreement.

In May 2018, the European Commission proposed emission limits for trucks, representing $27 \%$ of $\mathrm{CO}_{2}$ emissions from road transport in the EU 28. Road transport's share of total greenhouse gas emissions is increasing, and therefore reducing transport emissions is an important part of climate plans.

Trucks and bus transport will produce $1 / 3$ of $\mathrm{CO}_{2}$ emissions from road transport and $7 \%$ of total greenhouse gas emissions in the EU 28. In Slovakia it has been around $45 \%$ in the long term, well above the EU18 average. In addition to transport, industry and energy sectors has the largest additions in the total emissions.

The following figures show a comparison of the share of transport in total emissions by 2016 in the EU and the Slovak Republic.
Road transport has the largest share of transport emissions, dominated by the use of both diesel as well as passenger cars.

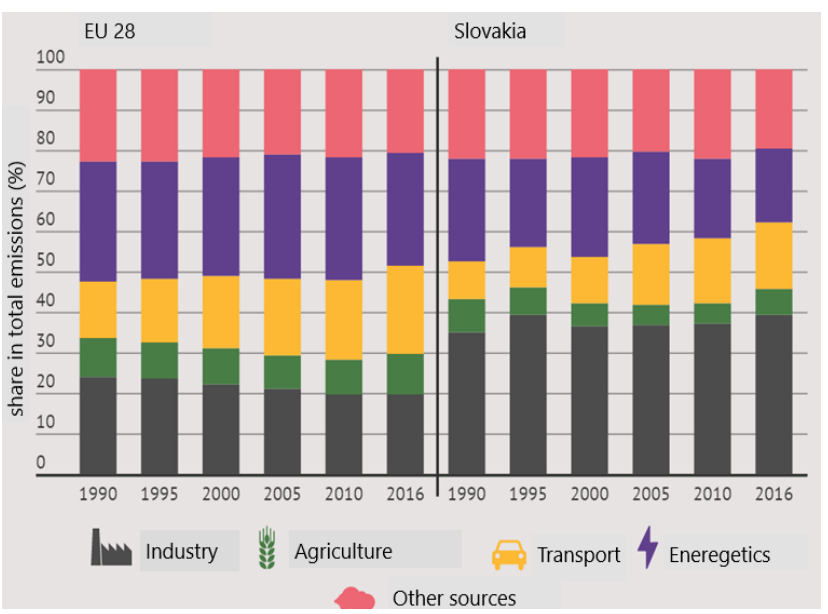

Fig. 13. The share of transport in total emissions in the EU and Slovakia

The following figure graphically shows the share of individual transport modes in the total amount of emissions from transport in the $\mathrm{EU}$ and the Slovak Republic. It is clear from the chart that the greatest share of air pollution in both cases is accounted for by individual car transport and the smallest share is contributed by rail transport. 


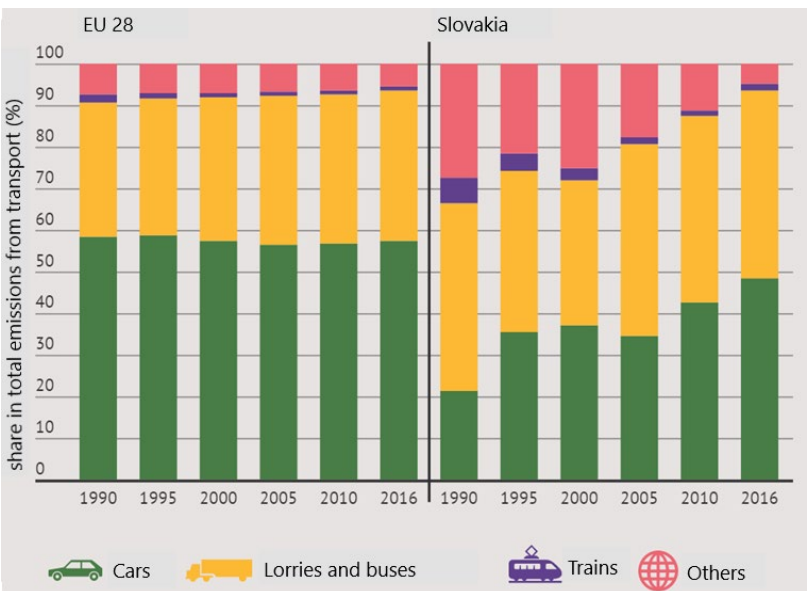

Fig. 14. Share of individual types of transport in total emissions from transport in EU and SR

Road transport is an economic sector that is developing worldwide on most indicators such as fuel consumption, i.e. the number of cars and transport performance considerably faster than GDP growth (this also causes and increases the associated environmental and health damage). In total, it has a negative impact on all environmental elements. To a large extent the air is affected by the combustion of hydrocarbon fuels in internal combustion engines of vehicles and also by increased noise emissions as one of the significant risk

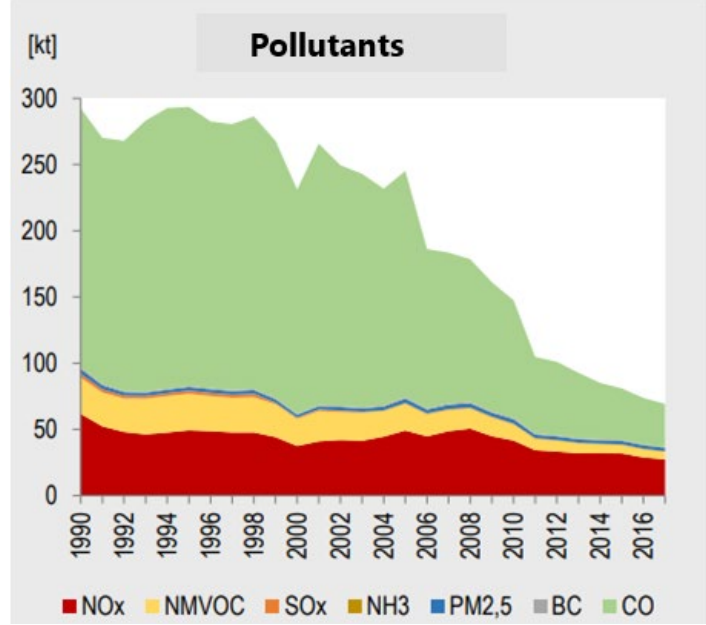

factors. Negative changes in the traffic situation mainly occur in cities and residential areas, i.e. areas close to exposed traffic routes, where the environmental burden and the health condition of the population are increased.

\subsection{Development of emissions in the transport sector in Slovakia}

In recent years, the development of emissions in the transport sector in Slovakia has seen a significant change in the use of public transport and its replacement by passenger cars. Simultaneously, the level of transit traffic (trucks) has also increased. Fuel consumption in rail transport has been increasing only slightly in recent years compared to road transport, which has seen a much steeper increase. Compared to 2005, emissions of pollutants decreased from $8 \%$ (sulphur oxides - SOx) to $81 \%$ (carbon monoxide). Simultaneously, heavy metal emissions increased significantly by $29 \%$ and POPs by $63 \%$. Most heavy metal emissions come from wheel abrasions, roads and brakes, which are emissions unrelated to the combustion of fuels. Increasing traffic intensity and aggressive driving have a significant impact on the increase in these emissions.

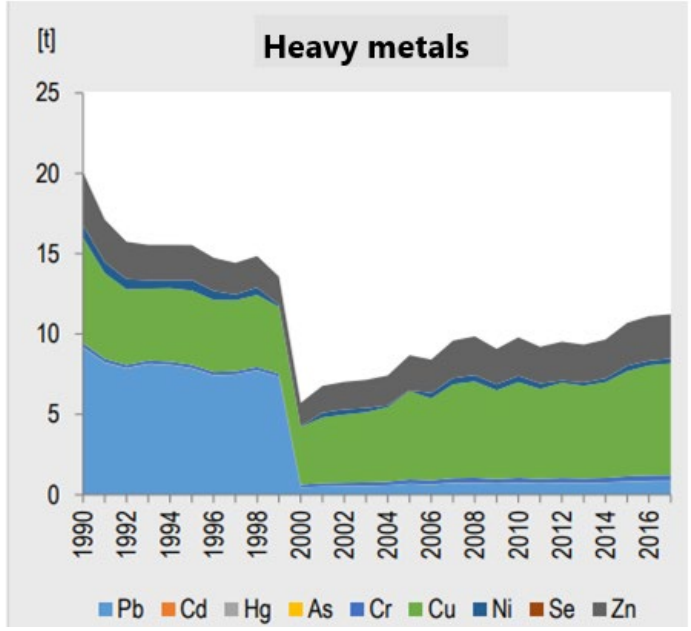

Fig. 15. Development of pollutants in the Slovak Republic in the transport sector in 1990-2017

Emissions that are not visible in the graphs are still produced by the processes, but at a much lower rate than other pollutants. However, for some substances, even small amounts may be significant.

\section{Conclusion}

The transition to greener transport in cities is facilitated by lower vehicle size requirements and higher population density. Public transport has more choices, and cycling and walking join that. The biggest problems of cities are congestion, poor air quality and noise. Urban transport accounts for approximately one quarter of $\mathrm{CO}_{2}$ emissions from transport and $69 \%$ of traffic accidents occur in cities. The gradual phasing out of 'conventionally powered' (using non-hybrid internal combustion engines) vehicles from the urban environment contributes most to a significant reduction in oil dependency, greenhouse gas emissions, urban air pollution and noise. This procedure will need to be complemented by the development of suitable fuel / charging infrastructures for new vehicles.

Increasing the share of travel in public transport, together with minimum service obligations, will make it possible to increase the density and frequency of 
transport services and therefore create a positive chain reaction in the various public transport modes. Spatial planning can also contribute to reducing traffic

\section{Acknowledgements}

The paper is supported by the VEGA Agency by the Project 1/0791/18"The Assessment of Economic and Technological Aspects in the Provision of Competitive Public Transport Services in Integrated Transport Systems" that is solved at Faculty of Operation and Economics of Transport and Communications, University of Žilina.

\section{References}

Aggelakakis A., Anagnostopoulou A. Tromaras A., Boile M., Mantzinou N. 2019. Influence of traffic emissions on urban air quality: A case study of a medium sized city. Advances in Intelligent Systems and Computing. 4th Conference on Sustainable Urban Mobility, CSUM 2018; Skiathos Island; Greece; 24 May 2018 through 25 May 2018. Volume 879, 2019, Pages 323-329

Baran J., Górecka A.K., 2019. Economic and environmental aspects of inland transport in EU countries. Economic Research-Ekonomska Istrazivanja, Volume 32, Issue 1, 1 January 2019, Pages 1037-1059

Čechovič, T., Dedík, M., Kendra, M., Opportunities for solving urban and environmental problems by progressive city logistics tools. 2019. [online]. Dostupné na internete: https://content.sciendo.com/view/journals/ttt/15/1/articlep1.xml

EEA.EUROPA.EU, $2017 . \quad$ Online available: https://www.eea.europa.eu/sk/signaly-eea/signaly2017/clanky/energy-in-europe-2014-state-1-sk

ENERGIE-PORTAL.SK, 2017. Online available: https://www.energie-portal.sk/Dokument/biopaliva100395.aspx

ENVIROPORTAL.SK, 2018. Online available: https://www.enviroportal.sk/indicator/detail?id=141\&print $=$ yes

EUCAR, CONCAVE, JRC: Well to Wheels Analysis of Future Automotive Fuels and Powertrains in the European Context. Online available: http://ies.jrc.ec.europa.eu/WTW

EURACTIV.SK, 2019. Online available: https://euractiv.sk/section/ovzdusie/infographic/emisie-zdopravy-rastu/

Jebli, B. M., Youssef, B. S., Apergis, M. - The dynamic linkage between renewable energy, tourism, CO 2 emissions, economic growth, foreign direct investment, and trade; Latin American Economic Review, Vol. 28, Issue 1, 2019, Article number 2

Kendra, M. a kol.: Energy intensity of railway and road passenger transport and its breaking point according to vehicle capacity usage, Proceedings of 7th Transport Research Arena TRA 2018, Viedeň, Rakúsko, 2018.

Muntean M., Guizzardi D., Schaaf E., Crippa M., Solazzo E., Oliver J.. 2018. Fossil CO2 emissions of all world countries - Report, Publications Office of the European Union 2018, 241p., ISBN 978-92-79-97240-9

MŽPSR.SK, 2017. Environmental report of the Slovak Republic 2017, Online available: https://www.enviroportal.sk/spravy/kat21

SHMU.SK, 2018. Air quality report of the Slovak Republic 2018. Online available:
http://www.shmu.sk/File/oko/rocenky/SHMU_Sprava_o_k valite_ovzdusia_SR_2018_v2.pdf

White paper - Roadmap to a Single European Transport Area Towards a competitive and resource efficient transport system, of 28 march 2011, KOM(2011) 144. 33s. Online available:

https://eurlex.europa.eu/LexUriServ/LexUriServ.do?uri=C OM:2011:0144:FIN:SK:PDF 